\title{
A Taxonomic Review of the Genus Microbispora by Analysis of Ribosomal Protein AT-L30
}

\author{
KOZO OCHI, ${ }^{1 *}$ KAZUTOMO HARAGUCHI, ${ }^{1}$ AND SHINJI MIYADOH ${ }^{2}$ \\ National Food Research Institute, 2-1-2 Kannondai, Tsukuba, Ibaraki 305, ${ }^{1}$ and Pharmaceutical \\ Research Center, Meiji Seika Kaisha, Ltd., Morooka, Kohoku-ku, Yokohama 222, ${ }^{2}$ Japan
}

\begin{abstract}
We analyzed the ribosomal AT-L30 proteins from 13 type strains of species belonging to the genera Microbispora and Actinomadura. The electrophoretic mobilities of the AT-L30 preparations from Microbispora strains, as determined by two-dimensional polyacrylamide gel electrophoresis, revealed that the members of the genus Microbispora are phylogenetically homogeneous. The results of partial amino acid sequencing of AT-L30 preparations from several representative Microbispora strains supported the separation of the genus Microbispora from other related genera. The amino acid sequences of the AT-L30 proteins from strains of species belonging to the genus Actinomadura sensu stricto displayed a diversity that exemplified the low levels of amino acid sequence homology within the genus. This diversity was considered to be a characteristic typical of the genus Actinomadura.
\end{abstract}

Analysis of rRNAs is already a well-accepted approach for studying the evolutionary relationships among microorganisms. This method has been applied successfully to the taxonomy of actinomycetes $(24,25)$. Ribosomal proteins could also be an excellent object of study, because ribosomal proteins have been shown to have lower evolutionary rates than other proteins (8). Since the recent discovery of heterogeneity among the ribosomal proteins of Streptomyces species (15), Ochi and coworkers have explored the phylogenetic relationships among groups of actinomycetes as determined by ribosomal protein AT-L30 analysis (17-21). Analysis of AT-L30 proteins by two-dimensional polyacrylamide gel electrophoresis (PAGE) has been used successfully to establish the taxonomic status of the genera Nocardia, Rhodococcus, Gordona, and Tsukamurella (17). Furthermore, the taxonomic status of representatives of the validly described genera classified in the family Pseudonocardiaceae has also been determined by analysis of their AT-L30 proteins (21). In particular, this new approach was effective for investigating the phylogenetic relationships among the taxa belonging to the family Streptosporangiaceae, which was previously called maduromycetes by Goodfellow and Cross (5). Ochi et al. (20) analyzed the AT-L30 proteins of members of the genera Actinomadura and Microtetraspora by using two-dimensional PAGE and demonstrated that these genera can be separated by using the electrophoretic properties of the AT-L30 proteins; the results were completely consistent with the previous conclusion of Kroppenstedt et al. (10), which was based on chemical, molecular, and numerical taxonomic evidence. Subsequently, on the basis of amino acid sequence homologies of AT-L30 proteins, we stressed that each of the three morphologically distinct groups of the genus Streptosporangium (14) merits separate generic status (19). As recently proposed by Miyadoh et al. (11), the genus Microbispora, another member of the family Streptosporangiaceae, currently contains only two species (Microbispora rosea and Microbispora bispora) as a result of the combining of numerous species into Microbispora rosea. In this study, we applied our new approach to the genus Microbispora to clarify the taxonomic status of this genus.

\footnotetext{
* Corresponding author.
}

\section{MATERIALS AND METHODS}

Bacterial strains. The strains used in this study are listed in Table 1. All of these strains were type strains that were obtained from the Japan Collection of Microorganisms, Saitama, Japan, the Institute of Fermentation, Osaka, Japan, and the American Type Culture Collection, Rockville, Md. Most of the strains were grown to mid-exponential phase in soluble starch-Polypeptone-yeast extract medium (15) at $30^{\circ} \mathrm{C}$ for 20 to $40 \mathrm{~h}$; the exceptions were Microbispora bispora, which was grown at $55^{\circ} \mathrm{C}$, and Microbispora aerata, Microbispora thermodiastatica, and Microbispora thermorosea, which were grown at $45^{\circ} \mathrm{C}$.

Two-dimensional PAGE. Two-dimensional PAGE by the method of Kaltschmidt and Wittmann (9) has been described in detail previously (15). After each slab gel was stained with Coomassie blue, the AT-L30 protein spot was identified. The electrophoretic mobilities (in the first dimension) of the AT-L30 proteins were expressed as relative electrophoretic mobilities (REMs) compared with the electrophoretic mobility of Saccharomonospora viridis AT-L30 protein, which exhibited the greatest mobility of all of the actinomycete AT-L30 proteins examined. The reference point for the REMs (a value of zero) was defined as the center point of each sample gel disk in the first electrophoretic dimension. Gels were run twice for each ribosomal protein sample to confirm the reproducibility of the results obtained.

Determination of amino acid sequence. The amino acid sequence analysis of each AT-L30 protein was carried out as described previously (19) by using a model 470A protein sequencer (Applied Biosystems, Foster City, Calif.). Determination of a maximum of $20 \mathrm{~N}$-terminal amino acids was possible; an amino acid residue of this size represents about one-third of the whole AT-L30 protein, assuming that the L30 protein from Escherichia coli (58-amino-acid residue) and the AT-L30 protein from actinomycetes are of the same size. The levels of similarity of the amino acid sequences (SAS values) were expressed as numbers of amino acid positions that were the same per number of positions compared. Positions that were not determined were not used in the calculations of SAS values. 
TABLE 1. Electrophoretic mobilities of ribosomal AT-L30 proteins from the type strains of species belonging to the genus Microbispora and related genera

\begin{tabular}{|c|c|c|}
\hline Strain $^{a}$ & $\begin{array}{l}\text { Mobility of } \\
\text { AT-L30 } \\
\text { protein } \\
(\mathrm{mm})^{b}\end{array}$ & $\operatorname{REM}^{c}$ \\
\hline Microtetraspora glauca $\mathrm{JCM} 3300^{\mathrm{T}}$ & -3.5 & $-5.0^{d}$ \\
\hline Microbispora aerata IFO $12581^{\mathrm{T}}$ & 4.3 & 6.5 \\
\hline Microbispora chromogenes $\mathrm{JCM} 3022^{\mathrm{T}}$ & 5.0 & 7.5 \\
\hline Microbispora karmatakensis ATCC $35927^{\mathrm{T}}$ & 5.7 & 8.5 \\
\hline Microbispora parva JCM $3024^{\mathrm{T}}$ & 5.7 & 8.5 \\
\hline Microbispora thermorosea IFO $14047^{\mathrm{T}}$ & 7.1 & 10.5 \\
\hline Microbispora thermodiastatica IFO $14046^{\mathrm{T}}$ & 8.6 & 12.5 \\
\hline Microbispora amethystogenes $\mathrm{JCM} 3021^{\mathrm{T}}$ & 9.3 & 13.5 \\
\hline Microbispora diastatica JCM $3023^{\mathrm{T}}$ & 9.3 & 13.5 \\
\hline Microbispora bispora ATCC $19993^{\mathrm{T}}$ & 14.3 & 21.0 \\
\hline Microbispora indica ATCC $35926^{\mathrm{T}}$ & 20.0 & 29.0 \\
\hline Microbispora rosea JCM $3006^{\mathrm{T}}$ & 20.0 & 29.0 \\
\hline $\begin{array}{l}\text { Actinomadura rugatobispora } \\
\quad \text { (Microbispora viridis) IFO } 14382^{T}\end{array}$ & 10.7 & 15.5 \\
\hline Actinomadura atramentaria $\mathrm{JCM} 6250^{\mathrm{T}}$ & 11.5 & $16.5^{d}$ \\
\hline Actinomadura madurae ATCC $19425^{\mathrm{T}}$ & 13.0 & $19.0^{d}$ \\
\hline Actinomadura malachitica $\mathrm{JCM} 3297^{\mathrm{T}}$ & 14.5 & $21.0^{d}$ \\
\hline $\begin{array}{l}\text { Actinomadura echinospora (Microbispora } \\
\text { echinospora) ATCC } 27300^{\mathrm{T}}\end{array}$ & 15.7 & 23.0 \\
\hline Actinomadura cremea IFO $14182^{\mathrm{T}}$ & 19.5 & $28.5^{d}$ \\
\hline Streptosporangium roseum $\mathrm{JCM} 2178^{\mathrm{T}}$ & 14.5 & $21.0^{d}$ \\
\hline Saccharomonospora viridis JCM $3036^{\mathrm{T}}$ & 68.5 & 100 \\
\hline
\end{tabular}

$a$ The names in parentheses are former names.

${ }^{b}$ Mobility of the AT-L 30 protein in the first dimension. A negative value indicates that the protein moved toward the reverse side (the anode side).

$c$ The mobility of protein AT-L30 from Saccharomonospora viridis JCM $3036^{\mathrm{T}}$ was defined as 100 .

${ }^{d}$ Data from references 19 and 20.

\section{RESULTS}

Two-dimensional PAGE analysis of ribosomal proteins. The ribosomal proteins of 11 species of the genus Microbispora were extracted with acetic acid and separated by twodimensional PAGE. The result obtained for Microbispora indica is shown in Fig. 1 as an example. When the ribosomal protein patterns of Microbispora species were compared, there were extensive similarities among 10 species (Microbispora aerata, Microbispora amethystogenes, Microbispora chromogenes, Microbispora diastatica, Microbispora indica, Microbispora karnatakensis, Microbispora parva, Microbispora rosea, Microbispora thermodiastatica, and Microbispora thermorosea); the only exception was Microbispora bispora, which produced a pattern that was very different from the patterns of the other Microbispora species (data not shown). It was also immediately evident that some of the spots represented homologous proteins. These proteins were designated AT-L30 proteins (Fig. 1, arrow) because of their levels of amino acid sequence homology (see below). The electrophoretic mobilities of the AT-L30 proteins in the first dimension of gel electrophoresis were different for the Microbispora species which we examined. The distances that the AT-L30 proteins moved in the first dimension in the original slab gels are shown in Table 1. Table 1 also shows the electrophoretic mobility of the AT-L30 protein from each species relative to the electrophoretic mobility of Saccharomonospora viridis AT-L30 protein, which exhibited the greatest mobility of all of the AT-L30 proteins from actinomycetes examined so far (17). The experimental error for the REMs defined in this way was $\leqq 5 \%$, as determined from several gel runs of the same

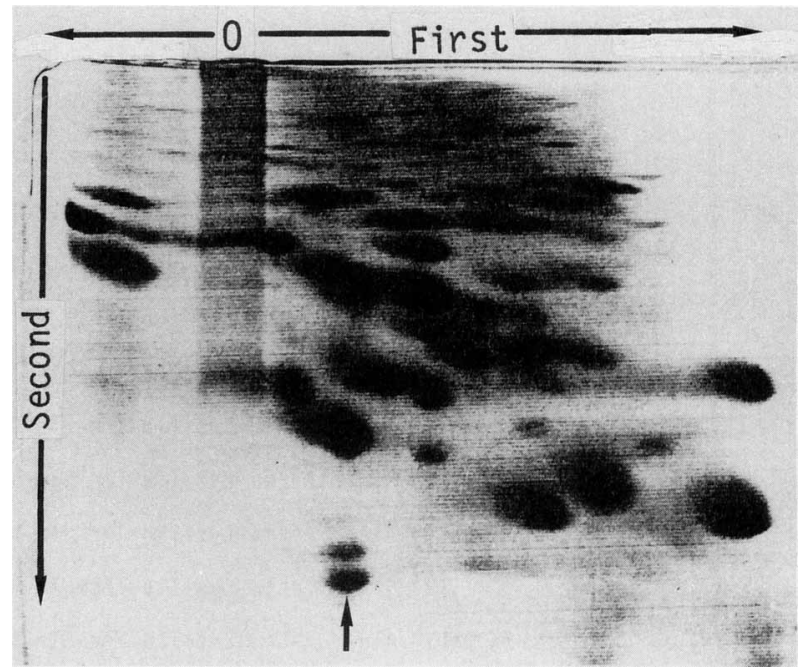

FIG. 1. Two-dimensional PAGE of total ribosomal proteins from Microbispora indica ATCC $35926^{\mathrm{T}}$ (T = type strain). O, origin in the first dimension. The arrow indicates the position of the AT-L30 protein.

sample. Table 1 shows that the members of the genus Microbispora that we tested displayed a relatively wide range of REMs (6.5 to 29.0). Actinomadura rugatobispora and Actinomadura echinospora were previously classified in the genus Microbispora (13). The REMs of these strains (15.5 and 23.0) (Table 1) fell within the REM ranges not only for the genus Actinomadura (REMs, 14.0 to 41.5) (20) but also for the genus Microbispora. Thus, to clarify the taxonomic status of the genera Microbispora and Actinomadura, it was necessary to conduct an amino acid sequence analysis of the AT-L30 proteins of these taxa.

Amino acid sequences of the AT-L30 proteins. As Fig. 2 shows, highly homologous sequences were found for the five Microbispora species examined. (Microbispora rosea, the type species of the genus, was not included in this study because of a difficulty in obtaining a sufficient amount of its AT-L30 protein for amino acid sequence analysis.) In contrast, sequences that exhibited less homology were found for the seven species of the genus Actinomadura examined. A comparison of the sequence of each AT-L30 protein with the known sequence of Escherichia coli L30 ribosomal protein (Ala-Lys-Thr-Ile-Lys-Ile-Thr-Gln-Thr-Gln-Thr-Arg-Ser-AlaIle-Gly. . . .) (23) showed considerable homology. These results provide strong evidence that the AT-L30 proteins in the Microbispora species which we tested are homologous to protein L30 of $E$. coli. To express quantitatively the levels of similarity of the amino acid sequences (SAS values), we determined the frequency of appearance of the same amino acid in 10 to $18 \mathrm{~N}$-terminal amino acids of each AT-L30 protein. The SAS values determined in this way for every combination of strains tested are shown in Table 2. Actinomadura verrucosospora was not included because of the low number of amino acids determined. It was striking that the members of the genus Microbispora had very high SAS values (91 to $100 \%)$ in comparisons with each other, indicating that the genus Microbispora is phylogenetically homogeneous. In contrast, the members of the genus Actinomadura had low SAS values (down to $67 \%$ ); SAS values greater than $90 \%$ were detected only in comparisons of Actinomadura madurae, Actinomadura echinospora, and Actinoma- 


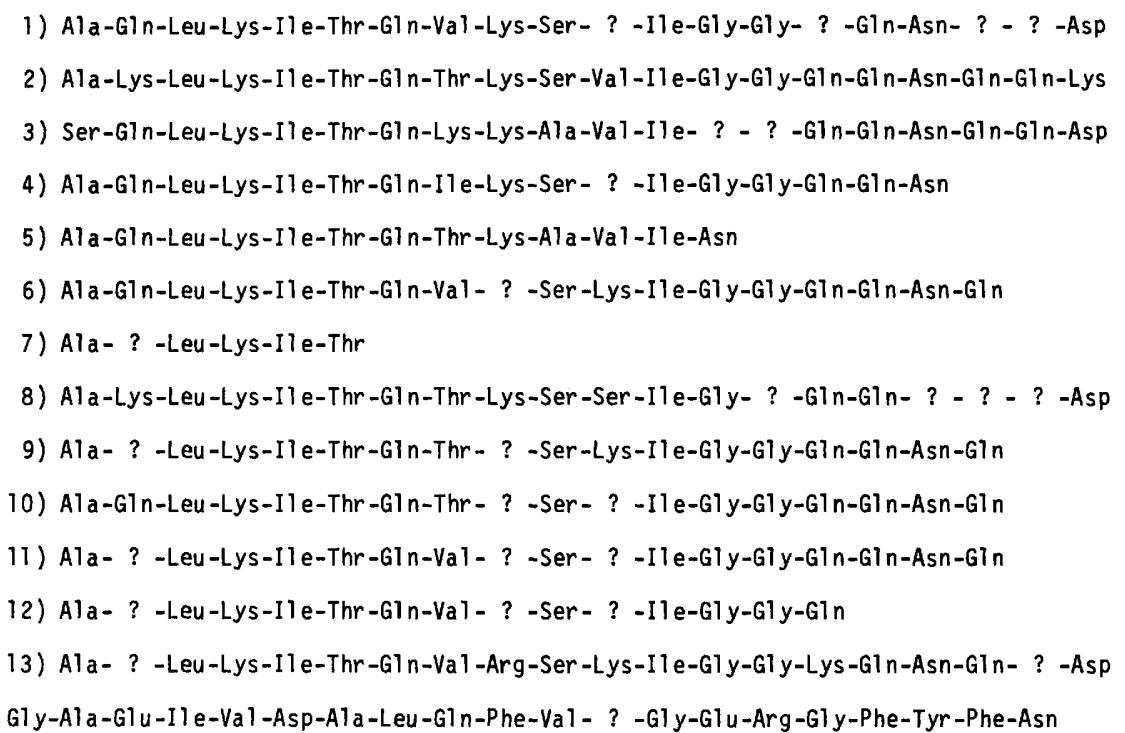

FIG. 2. Primary structures of $\mathrm{N}$ termini of AT-L30 proteins from several species of the genera Actinomadura and Microbispora. The data for Microtetraspora glauca and A. malachitica are from reference 20, and the data for Streptosporangium roseum are from reference 19. Question marks indicate amino acids that were not determined. Line $1, A$. madurae ATCC $19425^{\mathrm{T}}(\mathrm{T}=$ type strain); line 2, $A$. atramentaria JCM $6250^{\mathrm{T}}$; line $3, A$. cremea IFO $14182^{\mathrm{T}}$; line 4, . echinospora ATCC $27300^{\mathrm{T}}$; line 5, A. malachitica JCM $3297^{\mathrm{T}}$; line 6 , $A$. rugatobispora IFO $14382^{\mathrm{T}}$; line $7, A$. verrucosospora JCM $3147^{\mathrm{T}}$; line 8 , Microbispora amethystogenes JCM $3021^{\mathrm{T}}$; line 9 , Microbispora indica ATCC $35926^{\mathrm{T}}$; line 10, Microbispora aerata IFO $12581^{\mathrm{T}}$; line 11, Microbispora thermodiastatica IFO $14046^{\mathrm{T}}$; line 12 , Microbispora thermorosea IFO $14047^{\mathrm{T}}$; line 13, Streptosporangium roseum JCM $2178^{\mathrm{T}}$; line 14 , Microtetraspora glauca JCM $3300^{\mathrm{T}}$.

dura rugatobispora. Three other Actinomadura species (Actinomadura atramentaria, Actinomadura cremea, and Actinomadura malachitica) displayed low SAS values (72 to 83\%) in comparisons with each other (Table 2). It should also be pointed out that Actinomadura cremea had serine in the $\mathrm{N}$ terminus of its AT-L30 protein at a position that is occupied by alanine in the other AT-L30 proteins that have been examined so far (Fig. 2). Perhaps, this is a reflection of the observed diversity of the Actinomadura AT-L30 proteins. A dendrogram of the data in Fig. 2 is shown in Fig. 3.

\section{DISCUSSION}

The term maduromycetes was first introduced by Goodfellow and Cross (5) for a group of poorly circumscribed sporoactinomycetes that have a number of chemical and morphological features in common. The maduromycetes, which currently accommodates organisms that are assigned to the new family Streptosporangiaceae, include the sporangiate genera Streptosporangium, Planobispora, and Planomonospora, as well as the oligosporic genus Microbispora

TABLE 2. SAS values for the amino acid sequences of AT-L30 proteins ${ }^{a}$

\begin{tabular}{|c|c|c|c|c|c|c|c|c|c|c|c|c|}
\hline \multirow[b]{2}{*}{ Species } & \multicolumn{12}{|c|}{ SAS values $(\%)$} \\
\hline & 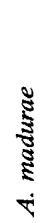 & 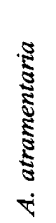 & $\begin{array}{l}\bar{\Xi} \\
\text { हैँ } \\
\dot{\nabla} \\
\dot{\nabla}\end{array}$ & 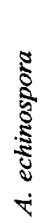 & 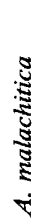 & 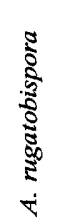 & 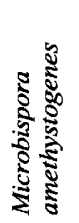 & 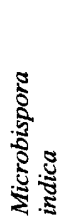 & 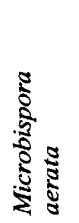 &  & $\begin{array}{l}5 \\
5 \\
5 \\
0 \\
5 \\
5 \\
5 \\
5\end{array}$ & 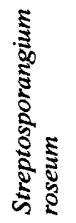 \\
\hline \multicolumn{13}{|l|}{ A. madurae } \\
\hline A. atramentaria & 81 & & & & & & & & & & & \\
\hline A. cremea & 79 & 72 & & & & & & & & & & \\
\hline A. echinospora & 93 & 88 & 79 & & & & & & & & & \\
\hline A. malachitica & 75 & 77 & 83 & 75 & & & & & & & & \\
\hline A. rugatobispora & 100 & 82 & 73 & 93 & 67 & & & & & & & \\
\hline Microbispora amethystogenes & 85 & 93 & 67 & 86 & 69 & 79 & & & & & & \\
\hline Microbispora indica & 92 & 94 & 71 & 93 & 73 & 94 & 92 & & & & & \\
\hline Microbispora aerata & 93 & 94 & 79 & 93 & 82 & 94 & 92 & 100 & & & & \\
\hline Microbispora thermodiastatica & 100 & 93 & 77 & 93 & 70 & 100 & 92 & 93 & 93 & & & \\
\hline Microbispora thermorosea & 100 & 92 & 70 & 92 & 70 & 100 & 91 & 92 & 92 & 100 & & \\
\hline Streptosporangium roseum & 93 & 72 & 63 & 80 & 58 & 94 & 73 & 82 & 87 & 93 & 92 & \\
\hline Microtetraspora glauca & 7 & 6 & 0 & 6 & 8 & 6 & 7 & 7 & 6 & 7 & 8 & 6 \\
\hline
\end{tabular}

${ }^{a}$ The SAS value for each pair of organisms for 10 to $18 \mathrm{~N}$-terminal amino acids of the AT-L30 proteins was determined on the basis of the data shown in Fig. 2. 


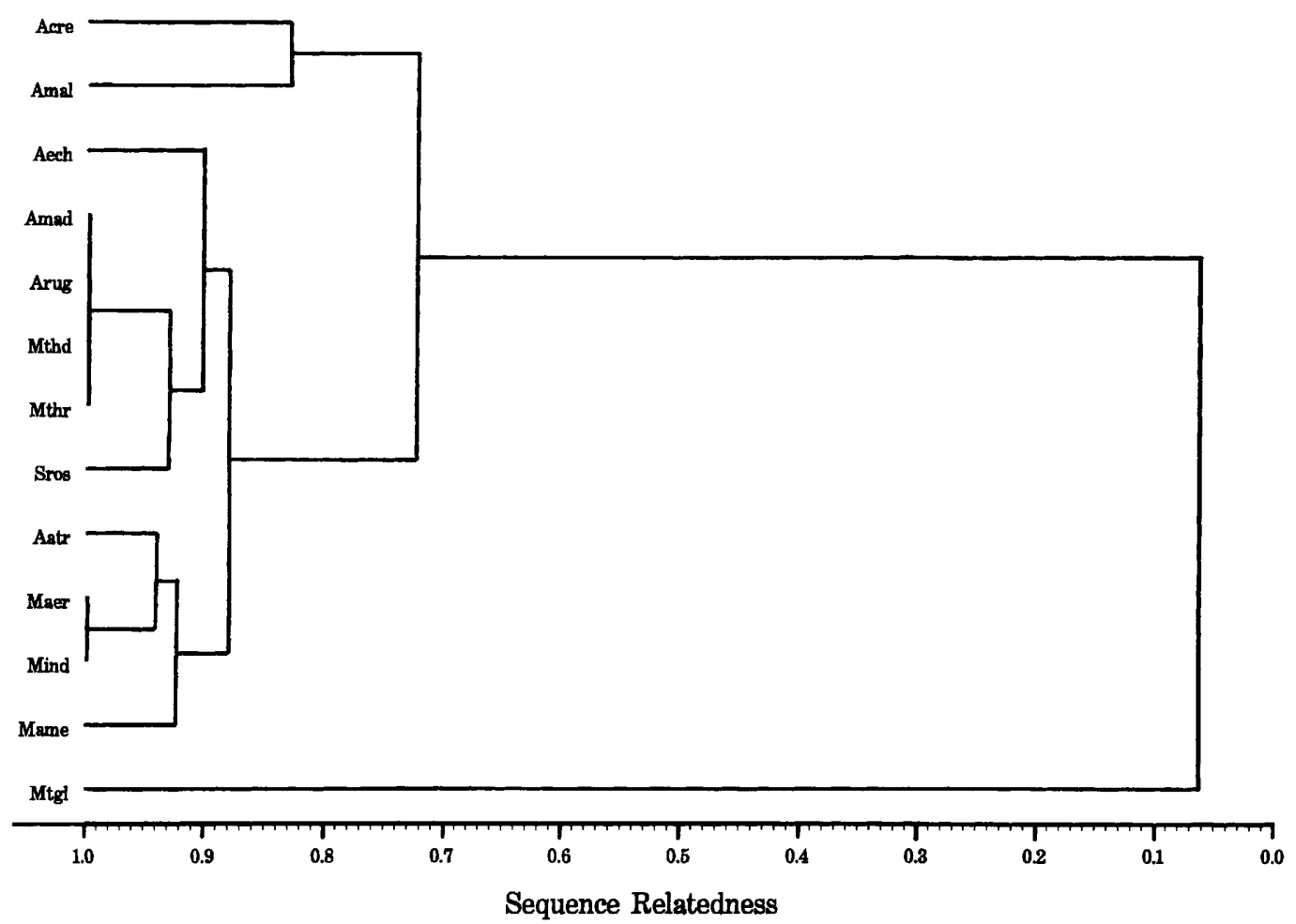

FIG. 3. Clustering of AT-L30 protein SAS values. The dendrogram was drawn by using the data in Fig. 2. Abbreviations: Acre, $A$. cremea; Amal, $A$. malachitica; Aech, $A$. echinospora; Amad, A. madurae; Arug, A. rugatobispora; Mthd, Microbispora thermodiastatica; Mthr, Microbispora thermorosea; Sros, Streptosporangium roseum; Aatr, A. atramentaria; Maer, Microbispora aerata; Mind, Microbispora indica; Mame, Microbispora amethystogenes; Mtgl, Microtetraspora glauca .

and the revised genus Microtetraspora $(3,7,10)$. These organisms contain meso-diaminopimelic acid and madurose (3-O-methyl-D-galactose) in their whole-cell hydrolysates. Among the genera of maduromycetes, all members of the genus Microbispora exhibit an unequivocal morphology characterized by the formation of longitudinally paired spores on aerial mycelia. Moreover, as determined by $\mathrm{Mi}$ yadoh et al. (11), these organisms have common chemotaxonomic phospholipid and menaquinone compositions. $\mathrm{Al}-$ though the members of the genus Microbispora can be divided into two groups on the basis of growth temperature requirements (14), they exhibit high SAS values in comparisons with each other (Table 2). As demonstrated in the genera Microtetraspora, Streptosporangium, and Streptomyces, we have found that the members of a well-demarcated genus exhibit SAS values higher than $90 \%$ (18a, 19, 20). Therefore, our ribosomal AT-L 30 protein analysis data, together with data from a previous study by Miyadoh et al. (11), confirm the phylogenetic status of the genus Microbispora as a single genus. Miyadoh et al. (11) also proposed that 10 Microbispora species other than Microbispora bispora should be combined into a single species with two subspecies (Microbispora rosea subsp. rosea and Microbispora rosea subsp. aerata). This view point was based mainly on the high levels of DNA relatedness among the $10 \mathrm{Microbi}$ spora species. On the other hand, Ochi (16) has shown that strains of a single species have virtually identical REM values for AT-L30 proteins, as demonstrated in various strains of Streptomyces lavendulae. Nevertheless, the 10 Microbispora strains displayed substantially different REMs (Table 1). Therefore, our data cast doubt on the previous view of Miyadoh et al. (11), although the 10 strains which we studied are closely related to each other, as demonstrated by the extensive similarity of their ribosomal protein patterns. On the other hand, Microbispora bispora clearly differs from these 10 strains at the species level.

$A$. echinospora and $A$. rugatobispora, which were previously classified in the genus Microbispora, both displayed high SAS values ( 93 and $100 \%$, respectively) in comparisons with $A$. madurae, the type species of the genus Actinomadura (Table 2 ). In contrast, these species displayed relatively low SAS values (86 and 79\%) in comparisons with Microbispora amethystogenes, an example of a Microbispora species. These observations support the view of Poschner et al. (22) and Miyadoh et al. (11) that Microbispora echinospora (=A. echinospora) and Microbispora viridis (= A. rugatobispora) should be classified as members of the genus Actinomadura instead of the genus Microbispora.

The genus Actinomadura has had a long and confusing taxonomic history. This genus was originally considered a member of the maduromycetes group, but is currently classified in the family Thermonosporaceae (6). It was surprising that, unlike the members of the genus Microbispora, the members of the genus Actinomadura displayed low SAS values (down to 67\%) in comparisons within the genus. Recently, a revision of the genus Actinomadura has been suggested by Goodfellow (4) and Miyadoh et al. (12); subsequently, on the basis of chemical, molecular, and numerical taxonomic evidence, Kroppenstedt et al. (10) proposed that Actinomadura pusilla and allied species should be viewed as a taxon that is independent from members of the genus Actinomadura sensu stricto and should be transferred to the 
genus Microtetraspora. The genus Actinomadura sensu stricto revised in this way is well defined and is characterized by many common properties among its species (10). The Actinomadura species used in this study were all members of Actinomadura sensu stricto. Therefore, the observed diversity in amino acid sequences (i.e., low SAS values) in Actinomadura AT-L30 proteins can be considered a characteristic of this genus. The diversity in AT-L30 proteins in the genus Actinomadura was expected from previous results that demonstrated that the range of REMs (14.0 to 41.5 ) for members of the genus Actinomadura sensu stricto is remarkably wide (20). These facts might imply that there is genetic instability within the genus Actinomadura, and such genetic instability, if any, might have led to the confusing taxonomic history of the genus Actinomadura and allied genera. A cluster analysis (Fig. 3) really demonstrated how confusing this situation is.

It is noteworthy that the members of the genus Microbispora exhibited high SAS values in comparisons with Streptosporangium roseum; this was especially pronounced with Microbispora thermodiastatica and Microbispora thermorosea (Table 2 and Fig. 3). Apparently, this is an indication of a close relationship between the genera Microbispora and Streptosporangium. The member of the genus Microtetraspora, another member of the maduromycetes, displayed extremely low SAS values (less than $8 \%$ ) not only in comparisons with members of the genus Streptosporangium but also in comparisons with members of the genus Microbispora (Table 2 and Fig. 3). However, previous investigations of the $16 \mathrm{~S}$ rRNA sequences demonstrated that the genus Microtetraspora is closely related to the genus Streptosporangium $(1,2)$. As discussed previously regarding this apparent incongruity (19), the true relationships are the relationships based on rRNA nucleotide sequences, given their agreement with the chemotaxonomic data. In the genus Microbispora, no data for rRNA nucleotide sequences have been reported.

Thus, to date, Ochi and coworkers have explored the efficacy of ribosomal protein patterns (for identification at the species level) and AT-L30 protein analysis (for classification at the genus level) as new approaches for the taxonomy of actinomycetes. It would be interesting to study whether the members of the genus Actinomadura exhibit diversity in rRNA sequences like that observed in the AT-L30 amino acid sequences.

\section{REFERENCES}

1. Fischer, A., R. M. Kroppenstedt, and E. Stackebrandt. 1983. Molecular-genetic and chemotaxonomic studies on Actinomadura and Nocardiopsis. J. Gen. Microbiol. 129:3433-3446.

2. Fowler, V. J., W. Ludwig, and E. Stackebrandt. 1985. Ribosomal ribonucleic acid cataloguing in bacterial systematics: the phylogeny of Actinomadura, p. 17-40. In M. Goodfellow and D. E. Minnikin (ed.), Chemical methods in bacterial systematics. Academic Press, London.

3. Goodfellow, M. 1989. Suprageneric classification of actinomycetes, p. 2333-2339. In S. T. Williams, M. E. Sharpe, and J. G. Holt (ed.), Bergey's manual of systematic bacteriology, vol. 4. The Williams \& Wilkins Co., Baltimore.

4. Goodfellow, M. 1989. Maduromycetes, p. 2509-2551. In S. T. Williams, M. E. Sharpe, and J. G. Holt (ed.), Bergey's manual of systematic bacteriology, vol. 4. The Williams \& Wilkins Co., Baltimore.

5. Goodfellow, M., and T. Cross. 1984. Classification, p. 7-164. In M. Goodfellow, M. Mordarski, and S. T. Williams (ed.), The biology of the actinomycetes. Academic Press, London.

6. Goodfellow, M., E. Stackebrandt, and R. M. Kroppenstedt. 1988. Chemotaxonomy and actinomycete systematics, p. 233-
238. In Y. Okami, T. Beppu, and H. Ogawara (ed.), Biology of actinomycetes '88. Japan Scientific Societies Press, Tokyo.

7. Goodfellow, M., L. J. Stanton, K. E. Simpson, and D. E. Minnikin. 1990. Numerical and chemical classification of Actinoplanes and some related actinomycetes. J. Gen. Microbiol. 136:19-36.

8. Hori, H., B. L. Lim, T. Ohta, T. Kumazaki, and S. Osawa. 1985. Evolution of organisms deduced from $5 \mathrm{~S}$ rRNA sequences, $\mathrm{p}$. 324-335. In T. Ohta and K. Aoki (ed.), Population genetics and molecular evolution. Japan Scientific Societies Press/Elsevier, Tokyo.

9. Kaltschmidt, E., and H. G. Wittmann. 1970. Ribosomal proteins. VII. Two-dimensional polyacrylamide gel electrophoresis analysis for finger-printing of ribosomal proteins. Anal. Biochem. 36:401-412.

10. Kroppenstedt, R. M., E. Stackebrandt, and M. Goodfellow. 1990. Taxonomic revision of the actinomycete genera Actinomadura and Microtetraspora. Syst. Appl. Microbiol. 13:148-160.

11. Miyadoh, S., S. Amano, H. Tohyama, and T. Shomura. 1990. A taxonomic review of the genus Microbispora and a proposal to transfer two species to the genus Actinomadura and to combine ten species into Microbispora rosea. J. Gen. Microbiol. 136: 1905-1913.

12. Miyadoh, S., H. Anzai, S. Amano, and T. Shomura. 1989. Actinomadura malachitica and Microtetraspora viridis are synonyms, and should be transferred as Actinomadura viridis comb. nov. Int. J. Syst. Bacteriol. 39:152-158.

13. Nonomura, H. 1989. Genus Microbispora, p. 2526-2531. In S. T. Williams, M. E. Sharpe, and J. G. Holt (ed.), Bergey's manual of systematic bacteriology, vol. 4. The Williams \& Wilkins Co., Baltimore.

14. Nonomura, H. 1989. Genus Streptosporangium, p. 2545-2551. In S. T. Williams, M. E. Sharpe, and J. G. Holt (ed.), Bergey's manual of systematic bacteriology, vol. 4. The Williams \& Wilkins Co., Baltimore.

15. Ochi, K. 1989. Heterogeneity of ribosomal proteins among Streptomyces species and its application to identification. J. Gen. Microbiol. 135:2635-2642.

16. Ochi, K. 1989. Taxonomic characterization of Streptomyces lavendulae by electrophoretic analysis of ribosomal proteins. Actinomycetologica 3:111-114.

17. Ochi, K. 1992. Electrophoretic heterogeneity of ribosomal protein AT-L30 among actinomycete genera. Int. J. Syst. Bacteriol. 42:144-150.

18. Ochi, K. 1992. Polyacrylamide gel electrophoresis analysis of ribosomal protein: a new approach for actinomycete taxonomy. Gene 115:261-265.

18a.Ochi, K. Unpublished data.

19. Ochi, K., and S. Miyadoh. 1992. Polyacrylamide gel electrophoresis analysis of ribosomal protein AT-L30 from an actinomycete genus, Streptosporangium. Int. J. Syst. Bacteriol. 42: $151-155$.

20. Ochi, K., S. Miyadoh, and T. Tamura. 1991. Polyacrylamide gel electrophoresis analysis of ribosomal protein AT-L 30 as a novel approach to actinomycete taxonomy: application to the genera Actinomadura and Microtetraspora. Int. J. Syst. Bacteriol. 41:234-239.

21. Ochi, K., and M. Yoshida. 1991. Polyacrylamide gel electrophoresis analysis of mycolateless wall chemotype IV actinomycetes. Int. J. Syst. Bacteriol. 41:402-405.

22. Poschner, J., R. M. Kroppenstedt, A. Fischer, and E. Stackebrandt. 1985. DNA-DNA reassociation and chemotaxonomic studies on Actinomadura, Microbispora, Microtetraspora, Micropolyspora and Nocardiopsis. Syst. Appl. Microbiol. 6:264 270.

23. Ritter, E., and B. Wittmann-Liebold. 1975. The primary structure of protein L30 from Escherichia coli ribosomes. FEBS Lett. 60:153-155.

24. Stackebrandt, E. 1991. Aspects on the evolution and phylogeny of the actinomycetes. Actinomycetologica 5:56-63.

25. Stackebrandt, E., and C. R. Woese. 1981. Towards a phylogeny of the actinomycetes and related organisms. Curr. Microbiol. 5:197-202. 